\title{
BET Inhibitor FT-1101
}

National Cancer Institute

\section{Source}

National Cancer Institute. BET Inhibitor FT-1101. NCI Thesaurus. Code C123733.

An orally bioavailable inhibitor of the Bromodomain and Extra-Terminal (BET) family of proteins, with potential antineoplastic activity. Upon administration, the BET inhibitor FT 1101 binds to the acetylated lysine recognition motifs in the bromodomain sites of BET proteins, thereby preventing the interaction between the BET proteins and acetylated histones. This disrupts chromatin remodeling and gene expression. Prevention of the expression of certain growth-promoting genes may lead to the inhibition of tumor cell growth. BET proteins, comprised of BRD2, BRD3, BRD4 and BRDT, are transcriptional regulators that play an important role during development and cellular growth. 